\title{
FAKTOR IBU DAN WAKTU PEMBERIAN MPASI BERHUBUNGAN DENGAN STATUS GIZI BALITA DI KABUPATEN KUPANG
}

\author{
Asweros Umbu Zogara*, Meirina Sulastri Loaloka, Maria Goreti Pantaleon \\ Program Studi Gizi, Politeknik Kesehatan Kementerian Kesehatan Kupang, \\ Jalan RA. Kartini I, Kelapa Lima, 85228, Kota Kupang, Nusa Tenggara Timur, Indonesia \\ *Korespondensi : E-mail: eroz.zogara@gmail.com
}

\begin{abstract}
Background:Children under five years old are very prone to the health problems due to a nutritional problem because they are the beginning of children's growth and development. Children who are malnourished will be at risk of experiencing health problems in the future. The causes of nutritional problems in children were the factor of parents because they are still dependent on their parents, and early complementary feeding.

Objectives:The aim of this study was to analyze the relationship between maternal factors and the timing of complementary feeding with the nutritional status of children under five in Kabupaten Kupang.

Methods:The research was conducted in Desa Oefeto and Raknamo, Kecamatan Amabi Oefeto, Kabupaten Kupang on September to December 2019. The research was used cross sectional design study. The research sample consisted of 229 children and the data were analyzed by using the chi square test.

Results:The results showed that the factors related to the nutritional status of children under five were mother's education $(p$ value $=0.001)$, maternal nutritional knowledge $(p$ value $=0.001)$, maternal nutritional behavior $(p$ value $=0.001)$, and the time of giving complementary foods ( $p$ value $=0.001)$, while mother's job ( $p$ value $=0.783)$, and the mother's attitude about nutrition $(p$ value $=0.355$ ) were not related to the nutritional status of children underfive.

Conclusion:Interventions need to be carried out on factors related to the nutritional status of children under five, including increasing nutritional knowledge and the application of maternal nutritional behavior.
\end{abstract}

Keywords: children under five, complementary feeding, maternal factors, nutritional status

\begin{abstract}
ABSTRAK
Latar belakang: Balita sangat rawan mengalami gangguan kesehatan akibat dari masalah gizi karena balita menjadi awal dari pertumbuhan dan perkembangan anak. Balita yang kekurangan gizi akan berisiko mengalami masalah kesehatan di masa mendatang. Penyebab masalah gizi pada balita antara lain, faktor orang tua karena balita masih sangat bergantung dengan orang tua, serta pemberian MPASI dini.

Tujuan: Penelitian ini bertujuan untuk menganalisis hubungan antara faktor ibu dan waktu pemberian MPASI dengan status gizi balita di Kabupaten Kupang.

Metode: Penelitian dilaksanakan di Desa Oefeto dan Raknamo, Kecamatan Amabi Oefeto, Kabupaten Kupang pada bulan September sampai Desember 2019. Desain penelitian yang digunakan adalah studi cross sectional. Sampel penelitian berjumlah 229 balita dan data dianalisis menggunakan uji chi square.

Hasil: Hasil penelitian menunjukkan faktor-faktor yang berhubungan dengan status gizi balita adalah pendidikan ibu ( $p$ value $=0,001$ ), pengetahuan gizi ibu ( $p$ value $=0,001$ ), perilaku gizi ibu ( $p$ value $=0,001$ ), dan waktu pemberian MPASI ( $\mathrm{p}$ value $=0,001)$, sedangkan pekerjaan ibu ( $\mathrm{p}$ value $=0,783)$, dan sikap ibu tentang gizi $(\mathrm{p}$ value $=0,355)$ tidak berhubungan dengan status gizi balita.

Kesimpulan: Intervensi perlu dilakukan terhadap faktor-faktor yang berhubungan dengan status gizi balita, antara lain peningkatan pengetahuan gizi, serta penerapan perilaku gizi ibu.
\end{abstract}

Kata kunci: balita, MPASI, faktor ibu, status gizi 


\section{PENDAHULUAN}

Masalah gizi pada balita masih menjadi masalah kesehatan di banyak negara. Di sebagian besar negara, masalah gizi terjadi karena kekurangan dan kelebihan asupan zat gizi, serta penyakit infeksi, sedangkan di negara berkembang dan miskin, persoalan gizi terutama berkaitan dengan kekurangan asupan sehingga mengakibatkan defisiensi zat gizi, seperti kekurangan energi, protein, zat besi, iodium, dan kekurangan mineral mikro lainnya. ${ }^{1}$ Sebelum pandemi Covid 19 melanda dunia, diperkirakan 47 juta balita terdampak wasting. Ini dapat diartikan sekitar 6,7 balita mengalami wasting pada 12 bulan pertama saat pandemi, yang mana $80 \%$ berada di Sub Sahara Afrika dan Asia Selatan dan lebih dari 10.000 balita meninggal setiap bulannya pada periode yang sama. ${ }^{2,3}$ Data lainnya di India tahun 2017 menunjukkan prevalensi stunting berkisar $16,4 \%$ sampai $62,8 \%$, wasting $5,5 \%$ sampai $30 \%$, dan underweight $11 \%$ sampai $51 \%{ }^{4}$

Riset Kesehatan Dasar (Riskesdas) tahun 2018 menunjukkan 3,5\% dan $6,7 \%$ balita mengalami masalah gizi sangat kurus dan kurus. Provinsi Nusa Tenggara Timur (NTT) merupakan salah satu provinsi di Indonesia yang angka masalah gizi melebihi angka nasional. Berdasarkan indikator BB/TB, sebanyak $4,6 \%$ dan $8,2 \%$ balita mengalami sangat kurus dan kurus. Kabupaten Kupang menjadi salah satu kabupaten di Provinsi NTT yang persentase balita bermasalah gizi cukup tinggi. Persentase balita gizi sangat kurus sebanyak $3,83 \%$ dan gizi kurus $8,89 \%$. Selain itu, balita yang mengalami gizi buruk dan gizi kurang masingmasing sebanyak 6,12\% dan 30,21\%. Masalah pendek dan sangat pendek juga banyak terjadi pada balita sebanyak $27,71 \%$ dan $13,73 \% .^{5}$

Balita sangat rawan mengalami gangguan kesehatan akibat dari masalah gizi karena balita menjadi awal dari pertumbuhan dan perkembangan anak. Balita yang kekurangan gizi akan berisiko mengalami penurunan IQ, penurunan imunitas dan produktivitas, masalah kesehatan mental dan emosional, serta kegagalan pertumbuhan. ${ }^{6}$ Gizi kurang pada balita, membawa dampak negatif terhadap pertumbuhan fisik maupun mental, yang selanjutnya akan menghambat prestasi belajar. Akibat lainnya adalah penurunan daya tahan, menyebabkan hilangnya masa hidup sehat balita, serta dampak yang lebih serius adalah timbulnya kecacatan, tingginya angka kesakitan dan percepatan kematian. $^{7}$

Salah satu penyebab masalah gizi pada balita adalah faktor orang tua karena balita masih sangat bergantung dengan orang tua. Selain itu, praktek pemberian makan juga turut mempengaruhi status gizi anak. Praktek pemberian makan yang dimaksud adalah pemberian makanan pendamping ASI (MPASI) dini. Faktor orang tua yang berhubungan dengan masalah gizi pada balita, antara lain pendidikan ${ }^{8}$ dan pekerjaan orang tua $^{9}$, serta pengetahuan, sikap, dan perilaku ibu tentang gizi. ${ }^{10-12}$

Organisasi Kesehatan Dunia (WHO) merekomendasikan bayi menyusui secara eksklusif untuk 6 bulan pertama kehidupan, diikuti dengan pengenalan makanan pelengkap yang memadai. ${ }^{13}$ Akan tetapi, banyak ibu yang telah memberikan makanan dan minuman lain selain ASI sebelum anak berumur 6 bulan. Beberapa faktor yang mempengaruhi ibu memberikan MPASI dini, antara lain pengetahuan ibu yang rendah tentang ASI eksklusif dan MPASI, serta ibu tidak mengetahui tahapan pemberian MPASI yang tepat. ${ }^{14}$ Faktor budaya dan peran nenek turut mempengaruhi ibu dalam memberikan MPASI dini. ${ }^{15}$

Pemberian MPASI terlalu awal dapat meningkatkan risiko kesakitan dan kematian bayi. ${ }^{15}$ Pemberian MPASI dini meningkatkan resiko penyakit infeksi, penghentian menyusui dan peningkatan konsumsi makanan manis dan berlemak. Ibu yang memberikan MPASI tepat waktu memiliki balita yang status gizi lebih baik menurut indikator $\mathrm{BB} / \mathrm{TB}$ dibandingkan ibu yang lebih awal memberikan MPASI kepada balita. ${ }^{16}$ Anak yang mendapatkan MPASI tepat waktu kurang berisiko mengalami malnutrisi kronis sebesar $25 \% .{ }^{17}$

Desa Oefeto dan Desa Raknamo berada dalam wilayah Kecamatan Amabi Oefeto di Kabupaten Kupang, Provinsi Nusa Tenggara Timur dan terletak tidak jauh dari ibukota kecamatan. Jumlah penduduk di Desa Raknamo lebih banyak dibandingkan Desa Oefeto. Berdasarkan penelusuran literatur, belum ada penelitian sebelumnya tentang masalah gizi pada balita di Desa Raknamo dan Desa Oefeto. 


\section{METODE}

Desain penelitian yang digunakan yaitu cross sectional. Penelitian dilakukan dari bulan September sampai Desember 2019 di Desa Oefeto dan Desa Raknamo, Kecamatan Amabi Oefeto, Kabupaten Kupang. Sampel dalam penelitian ini adalah balita berusia 0-59 bulan dengan jumlah 229 balita. Kriteria inklusi dalam penelitian ini adalah balita berusia 0-59 bulan, bertempat tinggal di Desa Oefeto dan Desa Raknamo, serta bersedia ikut serta dalam penelitian ini. Kriteria eksklusi, yaitu balita mengalami sakit dan tidak berada di tempat tinggal saat pengambilan data. Sampel dipilih menggunakan teknik simple random sampling. Cara pemilihan sampel, yaitu peneliti mengumpulkan data balita dari Puskesmas Fatukanutu, kemudian peneliti memilih secara acak berdasarkan data balita tersebut. Variabel penelitian meliputi variabel bebas dan variabel terikat. Variabel bebas meliputi faktor ibu dan pemberian MPASI dini. Faktor ibu meliputi pendidikan dan pekerjaan ibu, pengetahuan, sikap, dan perilaku gizi ibu. Variabel terikat, yaitu status gizi yang diperoleh dengan pengukuran tinggi atau panjang badan dan berat badan. Berat badan ditimbang menggunakan timbangan digital. Panjang badan diukur bagi balita berusia $<2$ tahun menggunakan length board, sedangkan tinggi badan bagi balita berusia $\geq 2$ tahun menggunakan microtoise. Penimbangan berat badan dan pengukuran panjang badan atau tinggi badan dilakukan satu kali. Selanjutnya status gizi dihitung menggunakan indikator $\mathrm{BB} / \mathrm{TB}$ atau $\mathrm{BB} / \mathrm{PB}$ dengan software WHO Anthro. Balita dikategorikan sangat kurus apabila nilai z-score <$3 \mathrm{SD}$, kurus $(-3)-(-2) \mathrm{SD}$, dan gizi baik $(-2)-2$ SD.

Data faktor ibu diperoleh menggunakan kuesioner. Data pendidikan ibu dibagi dalam dua kelompok, yaitu berpendidikan tinggi (tamat SMA dan tamat perguruan tinggi) dan berpendidikan rendah (tidak sekolah, tidak tamat SD, tamat SD, dan tamat SMP). Data pekerjaan ibu dikelompokkan berdasarkan dua ketegori, yaitu bekerja dan tidak bekerja (ibu rumah tangga). Pengetahuan, sikap, dan perilaku gizi ibu dikumpulkan melalui proses wawancara menggunakan kuesioner dan dibagi dalam 2 kategori, yaitu baik dan kurang. Kategori baik jika nilai $>60 \%$ dan kurang jika nilai $\leq 60 \%$. Waktu pemberian MPASI dibagi dalam 2 kategori, yaitu MPASI tepat waktu jika diberikan setelah umur 6 bulan dan MPASI dini jika diberikan sebelum umur 6 bulan. Peneliti menggunakan teknik probing dalam proses wawancara agar responden dapat mengingat kembali riwayat pemberian MPASI. Teknik analisis data yang digunakan adalah analisis univariat dan bivariat. Analisis univariat digunakan untuk melihat distribusi frekuensi dari variabel yang diteliti. Analisis bivariat digunakan untuk melihat hubungan faktor orang tua dan waktu pemberian MPASI dengan status gizi pada balita menggunakan uji chi square pada batas nilai $\mathrm{p}$ value sebesar 0,05 . Jika ada variabel yang tidak memenuhi syarat uji chi square, maka uji statistik yang digunakan adalah uji fisher exact.

\section{HASIL}

Tabel 1 menunjukkan sebagian besar ibu tidak bekerja (90,4\%), sedangkan ibu berpendidikan SD $(39,7 \%)$. Ibu yang berpengetahuan gizi kurang $(52,8 \%)$ lebih banyak dibandingkan berpengetahuan gizi baik $(47,2 \%)$. Sebagian besar ibu memiliki sikap gizi yang baik (57,6\%), sedangkan lebih banyak ibu berperilaku gizi kurang $(52,0 \%)$. Balita yang memperoleh MPASI tepat waktu $(58,1 \%)$ lebih banyak dibandingkan MPASI dini $(41,9 \%)$.

Tabel 2 menggambarkan hubungan variabel faktor ibu dan waktu pemberian MPASI dengan status gizi balita. Hasil uji statistik menunjukkan pendidikan ibu berhubungan dengan status gizi balita $(p=0,001)$. Balita yang bermasalah gizi lebih banyak memiliki ibu berpendidikan rendah dibandingkan balita berstatus gizi baik. Hasil uji statistik menunjukkan pengetahuan $(p=0,001)$ dan perilaku gizi ibu $(p=0,001)$ berhubungan dengan status gizi balita. Hasil uji statistik menunjukkan waktu pemberian MPASI berhubungan dengan status gizi balita $(p=0,001)$. Balita yang memperoleh MPASI dini lebih banyak mengalami masalah gizi, yaitu kurus dan sangat kurus. Pada variabel pekerjaan ibu dapat dilihat bahwa sebagian besar ibu tidak bekerja, baik pada balita gizi baik dan kurus. Hasil uji statistik menunjukkan pekerjaan ibu tidak berhubungan dengan status gizi balita $(p=0,355)$. 
Tabel 1. Distribusi frekuensi variabel penelitian

\begin{tabular}{lcc}
\hline \multicolumn{1}{c}{ Variabel penelitian } & n & $\%$ \\
\hline $\begin{array}{l}\text { Pekerjaan ibu } \\
\text { Tidak bekerja }\end{array}$ & 207 & 90,4 \\
$\quad$ Bekerja & 22 & 9,6 \\
Pendidikan ibu & & \\
$\quad$ Pendidikan tinggi & 169 & 73,8 \\
$\quad$ Pendidikan rendah & 60 & 26,2 \\
Pengetahuan gizi ibu & 108 & 47,2 \\
$\quad$ Baik & 121 & 52,8 \\
$\quad$ Kurang & 132 & 57,6 \\
Sikap gizi ibu & 97 & 42,4 \\
$\quad$ Baik & & 48,0 \\
$\quad$ Kurang & 110 & 52,0 \\
Perilaku gizi ibu & 119 & 58,1 \\
$\quad$ Baik & & 41,9 \\
$\quad$ Kurang & 133 & \\
$\quad$ Waktu pemberian MPASI & 96 & \\
$\quad$ MPASI tepat waktu & & \\
$\quad$ MPASI dini &
\end{tabular}

Tabel 2. Faktor-faktor yang berhubungan dengan status gizi

\begin{tabular}{|c|c|c|c|c|c|c|c|}
\hline \multirow{2}{*}{ Faktor-faktor } & \multicolumn{2}{|c|}{ Gizi baik } & \multicolumn{2}{|c|}{ Kurus } & \multicolumn{2}{|c|}{ Sangat kurus } & \multirow{2}{*}{ p value } \\
\hline & $\mathbf{n}$ & $\%$ & $\mathbf{n}$ & $\%$ & $\mathbf{n}$ & $\%$ & \\
\hline \multicolumn{8}{|l|}{ Pekerjaan ibu } \\
\hline Tidak bekerja & 139 & 90,8 & 33 & 91,7 & 35 & 87,5 & 0,783 \\
\hline Bekerja & 14 & 9,2 & 3 & 8,3 & 5 & 12,5 & \\
\hline \multicolumn{8}{|l|}{ Pendidikan ibu } \\
\hline Pendidikan tinggi & 101 & 66,0 & 32 & 88,9 & 36 & 90,0 & 0,001 \\
\hline Pendidikan rendah & 52 & 34,0 & 4 & 11,1 & 4 & 10,0 & \\
\hline \multicolumn{8}{|l|}{ Pengetahuan ibu } \\
\hline Baik & 88 & 57,5 & 10 & 27,8 & 6 & 15,0 & 0,001 \\
\hline Kurang & 65 & 42,5 & 26 & 72,2 & 34 & 85,0 & \\
\hline \multicolumn{8}{|l|}{ Sikap ibu } \\
\hline Baik & 86 & 56,2 & 19 & 52,8 & 27 & 67,5 & 0,355 \\
\hline Kurang & 67 & 43,8 & 17 & 47,2 & 13 & 32,5 & \\
\hline \multicolumn{8}{|l|}{ Perilaku ibu } \\
\hline Baik & 92 & 60,1 & 8 & 22,2 & 10 & 25,0 & 0,001 \\
\hline Kurang & 61 & 39,9 & 28 & 77,8 & 30 & 75,0 & \\
\hline \multicolumn{8}{|c|}{ Waktu pemberian MPASI } \\
\hline MPASI tepat waktu & 108 & 70,6 & 16 & 44,4 & 9 & 22,5 & 0,001 \\
\hline MPASI dini & 45 & 29,4 & 20 & 55,6 & 31 & 77,5 & \\
\hline
\end{tabular}

Penelitian ini menunjukkan lebih banyak ibu berpengetahuan kurang memiliki balita kurus. Hasil ini sama dengan penelitian di Nigeria. ${ }^{11}$ Di lokasi penelitian, sebagian besar ibu mendapatkan informasi gizi hanya di posyandu sebulan sekali. Kurangnya sumber informasi tentang gizi mengakibatkan banyak ibu yang berpengetahuan gizi kurang. Hasil uji statistik menunjukkan pengetahuan ibu berhubungan dengan status gizi balita. Penelitian lain di Banyumas (2016) dan Aceh (2020) juga menemukan hasil yang sama. ${ }^{21,22}$ Rendahnya pengetahuan tentang gizi menggambarkan kurangnya pendidikan gizi bagi ibu. Hal ini juga dapat dikaitkan dengan rendahnya tingkat pendidikan ibu. ${ }^{23}$ Pengetahuan ibu tentang gizi merupakan salah satu faktor yang berpengaruh 
terhadap jenis dan jumlah makanan yang dikonsumsi oleh anaknya. Oleh karena itu, pengetahuan ibu diharapkan berperan dalam peningkatan status gizi balita. ${ }^{24}$ Ibu dengan tingkat pengetahuan yang lebih baik kemungkinan besar akan menerapkan pengetahuannya dalam mengasuh anaknya, khususnya memberikan makanan sesuai dengan zat gizi yang diperlukan oleh balita, sehingga balita tidak mengalami kekurangan asupan makanan. ${ }^{6}$

Uji statistik menunjukkan perilaku gizi ibu berhubungan dengan status gizi balita. Hasil yang sama ditemukan oleh penelitian Hartono, dkk (2017) di Kalimantan Selatan dan Fajriani, dkk (2020) di Aceh. ${ }^{22,25}$ Perilaku gizi yang ditanyakan dalam penelitian ini, yaitu pemberian ASI, pemberian makan, penimbangan di posyandu, pemberian vitamin A, imunisasi, kebiasaan sarapan dan jajanan, serta penggunaan garam beryodium. Perilaku dipengaruhi oleh pengetahuan dan sikap. Pada penelitian Jayanti, dkk (2011) menunjukkan adanya korelasi positif antara pengetahuan dan perilaku gizi ibu. ${ }^{26}$ Artinya semakin tinggi tingkat pengetahuan gizi, maka semakin baik perilaku gizi ibu.

Berdasarkan uji statistik diketahui bahwa waktu pemberian MPASI berhubungan dengan status gizi balita. Hasil yang sama juga didapatkan oleh penelitian Asfaw, et al. (2015) di Ethiopia dan Jemide, et al. (2016) di Nigeria. ${ }^{12,27}$ Penelitian ini menyebutkan bahwa balita yang memperoleh MPASI dini lebih banyak mengalami masalah kurus dan sangat kurus dibandingkan balita yang mendapatkan MPASI tepat waktu. Pemberian MPASI dini dapat mengganggu pemberian ASI eksklusif serta menjadikan bayi rentan terhadap penyakit karena enzim pencernaan pada bayi belum mencapai jumlah yang cukup untuk mencerna makanan kasar sampai usia 6 bulan. ${ }^{28}$ Penyakit infeksi akan mengurangi nafsu makan dan secara langsung mempengaruhi metabolisme zat gizi dan menyebabkan rendahnya pemanfaatan zat gizi sehingga dapat mengakibatkan masalah gizi. ${ }^{1}$ Dalam pemberian MPASI, yang perlu diperhatikan adalah usia pemberian MPASI, jenis MPASI, frekuensi dalam pemberian MPASI, porsi pemberian MPASI, dan cara pemberian MPASI pada tahap awal. Pemberian makanan tambahan harus bervariasi, dari bentuk bubur cair kebentuk bubur kental, sari buah, buah segar, makanan lumat, makanan lembek dan akhirnya makanan padat. ${ }^{29}$

Hasil penelitian ini menunjukkan sebagian besar ibu tidak bekerja atau ibu rumah tangga. Hasil penelitian ini sama dengan penelitian Rohimah, et al (2015) di Kota Tangerang Selatan dan Beiersmannm et al (2013) di Burkina Faso. ${ }^{30,31}$ Uji statistik menunjukkan pekerjaan ibu tidak berhubungan dengan status gizi pada balita. Dua penelitian lain di Ethiopia oleh Woldeamanuel dan Tesfaye (2019), serta Amare et al (2019) juga menemukan hasil yang sama. ${ }^{32,33}$ Di lokasi penelitian, kebanyakan ibu tidak bekerja karena sebagian besar masyarakat masih menganggap tugas utama ibu adalah mengurus rumah tangga, sedangkan tugas ayah adalah bekerja.

Sikap ibu tentang gizi tidak berhubungan dengan status gizi pada balita. Sikap bukan suatu tindakan atau aktivitas, akan tetapi merupakan faktor predisposisi bagi seseorang untuk berperilaku. Sikap seseorang dipengaruhi oleh faktor internal, antara lain faktor psikologis dan fisiologis. Faktor eksternal berupa intervensi yang datang dari luar individu misalnya berupa pendidikan, pelatihan dan lainnya. ${ }^{34}$ Sikap belum tentu langsung dapat terwujud dalam bentuk perilaku karena diperlukan faktor pendukung lainnya, yaitu faktor lingkungan dan keluarga. ${ }^{35}$

\section{SIMPULAN}

Faktor-faktor yang berhubungan dengan gizi kurus pada balita adalah pendidikan, tingkat pengetahuan dan perilaku gizi ibu, serta waktu pemberian MPASI, sedangkan yang tidak berhubungan dengan status gizi balita adalah pekerjaan ibu dan sikap ibu tentang gizi.

Tenaga kesehatan di Puskesmas Futukanutu perlu melakukan sosialisasi mengenai gizi secara terus menerus sehingga meningkatkan pengetahuan gizi ibu. Selain itu perlu juga dilakukan pengawasan mengenai perilaku ibu yang berkaitan dengan gizi. Pihak pemerintah Desa Oefeto dan Raknamo harus mendukung seluruh program kesehatan termasuk yang berkaitan dengan peningkatan status gizi balita.

\section{UCAPAN TERIMA KASIH}

Tim peneliti menghaturkan banyak terima kasih kepada Poltekkes Kemenkes Kupang, Pemerintah Kabupaten Kupang, dan Kepala 
Puskesmas Fatukanutu, serta Kepala Desa Oefeto dan Desa Raknamo yang mengizinkan peneliti melakukan pengambilan data penelitian, serta seluruh pihak terkait yang telah membantu dalam bentuk dukungan moril, tenaga maupun materi sehingga dapat terlaksananya penelitian ini.

\section{DAFTAR PUSTAKA}

1. Kuntari T, Jamil NA, Kurniati O. Faktor risiko malnutrisi pada balita. Kesmas Natl Public Heal J. 2013; 7(12): 572-6.

2. Fore HH, Dongyu Q, Beasley DM, Ghebreyesus TA. Child malnutrition and COVID-19: the time to act is now. Lancet. 2020; 396: 517-8.

3. Headey D, Heidkamp R, Osendarp S, Ruel M, Scott N, Black R, et al. Impacts of COVID-19 on childhood malnutrition and nutrition-related mortality. Lancet. 2020; 396: 519-21.

4. Hemalatha R, Pandey A, Kinyoki D, Ramji S, Lodha R, Kumar GA, et al. Mapping of variations in child stunting, wasting and underweight within the states of India: the Global Burden of Disease Study 2000-2017. E Clinical Medicine. 2020;22: 1-16.

5. Badan Penelitian dan Pengembangan Kementrian Kesehatan RI. Laporan Hasil Riset Kesehatan Dasar (Riskesdas) Indonesia tahun 2018. Riset Kesehatan Dasar. Jakarta: Kemenkes RI. 2018.

6. Ni'mah C, Muniroh L. Hubungan tingkat pendidikan, tingkat pengetahuan dan pola asuh ibu dengan wasting dan stunting pada balita keluarga miskin. Media Gizi Indones. 2015; 10(1): 84-90.

7. Rahim FK. Faktor risiko underweight balita umur 7-59 bulan. KESMAS-J Kesehat Masy. 2014; 9(2): 115-21.

8. Rachmi CN, Agho KE, Li M, Baur LA. Stunting, underweight and overweight in children aged 2.0-4.9 years in Indonesia: Prevalence trends and associated risk factors. PLoS One. 2016; 11(5): 1-17.

9. Putri D, Wahyono T. Faktor langsung dan tidak langsung yang berhubungan dengan kejadian wasting pada anak umur $6-59$ bulan di Indonesia tahun 2010. Media Heal Res Dev. 2013; 23(3): 110-21.

10. Akeredolu I, Osisanya J., Seriki-Mosadolorun J., Okorafor U. Mothers' nutritional knowledge, infant feeding practices and nutritional status of children (0-24 Months) in Lagos State, Nigeria. Eur J Nutr Food Saf. 2014; 4(4): 364-74.

11. Berra WG. Knowledge, Perception and practice of mothers/caretakers and family's regarding child nutrition (under 5 years of age) in Nekemte Town, Ethiopia. 2013; 2(4): 7886.

12. Jemide J, Ene-Obong H, Edet E, Udoh E. Association of maternal nutrition knowledge and child feeding practices with nutritional status of children in Calabar South Local Government Area, Cross River State, Nigeria. Int J Home Sci. 2016; 2(1): 293-8.

13. Qasem W, Fenton T, Friel J. Age of introduction of first complementary feeding for infants: A systematic review. BMC Pediatr. 2015; 15: 107.

14. Zogara AU, Hadi H, Arjuna T. Riwayat pemberian ASI eksklusif dan MPASI dini sebagai prediktor terjadinya stunting pada baduta di Kabupaten Timor Tengah Selatan, Nusa Tenggara Timur. J Gizi dan Diet Indones. 2014; 2(1): 41-50.

15. Inayati D, Scherbaum V, Purwestri R, Hormann E, Wirawan N, Suryantan J, et al. Improved nutrition knowledge and practice through intensive nutrition education: A study among caregivers of mildly wasted children on Nias Island, Indonesia. Int Breastfeed J. 2012; 7(3): 117-27.

16. Udoh EE, Amodu OK. Complementary feeding practices among mothers and nutritional status of infants in Akpabuyo Area, Cross River State Nigeria. Springerplus. 2016; 5(2073): 1-19.

17. Saaka M, Wemakor A, Abizari AR, Aryee P. How well do WHO complementary feeding indicators relate to nutritional status of children aged 6-23 months in rural Northern Ghana? BMC Public Health. 2015; 15(1157): $1-12$.

18. Novignon J, Aboagye E, Agyemang OS, Aryeetey G. Socioeconomic-related inequalities in child malnutrition: evidence from the Ghana multiple indicator cluster survey. Health Econ Rev. 2015; 5(34): 1-11.

19. Akombi BJ, Agho KE, Hall JJ, Wali N, Renzaho AMN, Merom D. Stunting, wasting 
and underweight in Sub-Saharan Africa: A systematic review. Int $\mathbf{J}$ Environ Res Public Health. 2017; 14(863): 1-18.

20. Akombi BJ, Agho KE, Merom D, Hall JJ, Renzaho AM. Multilevel analysis of factors associated with wasting and underweight among children under-five years in Nigeria. Nutrients. 2017;9(1): 44.

21. Purwanti R, Wati EK, Rahardjo S. Karakteristik keluarga yang berhubungan dengan status gizi balita umur 6- 59 bulan. Jurnal Gizi Indonesia (The Indonesian Journal of Nutrition). 2016; 5(1): 50-4.

22. Fajriani F, Aritonang EY, Nasution $Z$. Hubungan pengetahuan, sikap dan tindakan gizi seimbang keluarga dengan status gizi anak balita usia 2-5 tahun. J Ilmu Kesehat Masy. 2020; 9(1): 1-11.

23. Imdad A, Yakoob MY, Bhutta ZA. Impact of maternal education about complementary feeding and provision of complementary foods on child growth in developing countries. BMC Public Health. 2011; 11(Suppl 3): S25--S39.

24. Octaviani IA, Margawati A. Hubungan pengetahuan dan perilaku ibu buruh pabrik tentang kadarzi (keluarga sadar gizi) dengan status gizi anak balita (studi di Kelurahan Pagersari, Ungaran). Journal of Nutrition College. 2012; 1(1): 46-54.

25. Hartono H, Widjanarko B, EM MS. Hubungan perilaku Keluarga Sadar Gizi (KADARZI) dan Perilaku Hidup Bersih Sehat (PHBS) pada tatanan rumah tangga dengan status gizi balita usia 24-59 bulan. Jurnal Gizi Indonesia (The Indonesian Journal of Nutrition. 2017; 5(2): 88-97.

26. Jayanti LD, Effendi YH, Sukandar D. Perilaku hidup bersih dan sehat (phbs) serta perilaku gizi seimbang ibu kaitannya dengan status gizi dan kesehatan balita di Kabupaten Bojonegoro, Jawa Timur. J Gizi dan Pangan. 2011; 6(3): 192-9.

27. Asfaw M, Wondaferash M, Taha M, Dube L. Prevalence of undernutrition and associated factors among children aged between six to fifty nine months in Bule Hora district, South Ethiopia. BMC Public Health. 2015; 15(41): 1-9.

28. Damayanti RA, Muniroh L, Farapti F. Perbedaan tingkat kecukupan zat gizi dan riwayat pemberian ASI eksklusif pada balita stunting dan non stunting. Media Gizi Indones. 2017; 11(1): 61-9.

29. Lestari MU, Lubis G, Pertiwi D. Hubungan pemberian makanan pendamping asi (mp-asi) dengan status gizi anak usia 1-3 tahun di Kota Padang Tahun 2012. J Kesehat Andalas. 2014; 3(2): 188-90.

30. Rohimah E, Kustiyah L, Hernawati N. Pola konsumsi, status kesehatan dan hubungannya dengan status gizi dan perkembangan balita. J Gizi dan Pangan. 2015; 10(2): 93-100.

31. Beiersmann C, Lorenzo JB, Bountogo M, Tiendrébeogo J, Gabrysch S, Yé M, et al. Malnutrition determinants in young children from Burkina Faso. J Trop Pediatr. 2013; 59(5): 372-9.

32. Woldeamanuel BT, Tesfaye TT. Risk factors associated with under-five stunting, wasting, and underweight based on ethiopian demographic health survey datasets in Tigray Region, Ethiopia. J Nutr Metab. 2019.

33. Amare ZY, Ahmed ME, Mehari AB. Determinants of nutritional status among children under age 5 in Ethiopia: Further analysis of the 2016 Ethiopia demographic and health survey. Global Health. 2019; 15(1): 111.

34. Sofiyana D, Noer ER. Perbedaan pengetahuan, sikap dan perilaku ibu sebelum dan setelah konseling gizi pada balita gizi buruk. Journal of Nutrition College. 2013; 2(1): 134-44.

35. Rakhmawati N, Panunggal B. Hubungan pengetahuan dan sikap ibu dengan perilaku pemberian makanan anak usia 12-24 bulan. Journal of Nutrition College. 2014; 3(1): 4350 . 